8. Постанови ЦК КПРС та Ради Міністрів СРСР 3 питань народної освіти УРСР // ЦДАВО України, ф. 166, оп. 15, спр. 1782, 60 арк.

9. Статвідділ. Відомості про навчання іноземної мови, 1952-53 навчальний рік // ЦДАВО Укр., ф. 166, оп. 15 , спр. 1108,120 арк.

10. Харьковский политехнический институт. 1885 - 1985: история развития. - Харьков : Изд-во Харьк. ун-та, 1985. - 223 с.
11. Ходаков В. Е. Высшее образование в Украине: взгляд со стороны и изнутри : монография / В. Е. Ходаков. - Херсон : Олди-плюс, 2001. - 214 с.

12. Юхно О. І. Діяльність політехнічних ВНЗ у контексті розвитку вищої технічної освіти в Україні (друга половина XX століття) : автореф. дис. на здобуття наук. ступеня канд. пед. наук : спец. 13.00.01 / О. І. Юхно. - Суми, 2016. - 20 с.

Дата надходження до редакиіï: 17.09.2019 p.

\title{
ТРАНСФОРМАЦІЯ ЖИТТЕВИХ ЦІННОСТЕЙ УКРАЇНСЬКИХ ТА АМЕРИКАНСЬКИХ СТУДЕНТІВ У ХХІ СТОЛІТТІ
}

У статті проаналізовано особливості трансформаиії життєвих иінностей украӥнських та американських студентів у XXI столітті в спектрі превалюючих освітніх прочесів та виховного потениіалу. 3'ясовано, щзо розвиток життєвих иінностей у студентів більшості закладів вишої освіти США здійснюється із застосуванням інтерактивних методів виховного впливу, зокрема створюються відповідні інтерактивні зони, забезпечується формат коучингу та фідбек-векторне спрямування, Skyре-простір i SPARK!LAB-nростір. Доведено, щчо виховний вплив у закладах вищої освіти України здійснюється на основі організації спеціальних освітніх курсів, семінарів, практикумів, дискусій та тренінгів; уроків особистої гідності, взаємоповаги та безконфліктної взаємодії в соиіумі; створення рольових ситуачій; використання відеороликів, онлайн-комунікаиії.

Ключові слова: життєві иінності, студенти, трансформація, інформачійне суспільство XXI століття, освітні процеси, виховний потенціал, інтерактивні інструменти.

B cтатье проанализированы особенности трансформации жизненных иенностей украинских и американских студентов в XXI веке в спектре превалируюших образовательных прочессов и воспитательного потенииала. Установлено, что развитие жизненных иенностей студентов в большинстве выстих учебных заведений США сегодня осуществляется с применением интерактивных методов воспитательного воздействия, в частности создаются соответствуюшие интерактивные зоньи, обеспечивается формат коучинга, работа идет согласно фидбэк-векторного направления, организуется Skype- и SPARK!LAB-nространства. Доказано, что воспитательное воздействие в учреждениях выстего образования Украины осуществляется на основе организации специиальных образовательных курсов, семинаров, практикумов, дискуссий и тренингов; уроков личного достоинства, взаимоуважения и бесконфликтного взаимодействия в соииуме; создания ролевых ситуаиий; использования видеороликов, онлайн-коммуникачии.

Ключевые слова: жизненные иенности, студенты, трансформачия, информачионное обшество XXI века, образовательные проиессы, воспитательный потенциал, интерактивные инструменты.

The article analyzes the features of the transformation of the living values of Ukrainian and American students at the XXI century at the spectrum of prevailing processes of vortex potential have been analyzed.

It's clear that the primary-whirlwind process in American mortgages is to open the cob of the XXI century. To live up to such students 'life: individuality, privacy, equality, time, informality, achievement \& hard work/play, direct \& assertive, looking to the future and to change. Introduce interactive methods of vortex inflow. I'm interfacing with interactive zones, securing coaching format, working with a simple feedback vector-based organization, organizing Skype-space and SPARK! LABspace.

In order to identify a system of life-saving and traditional Ukrainian students, the complex has been fully integrated: the questionnaire for $M$. Rokich's methodology, a series of formal studies, and a number of basic tests have been completed. A total of nearly thousand students (of the highest specialties and the highest categories) from the Kharkiv Humanitarian Pedagogical Academy have been fed; Vinnitsa cooperative institute; Transcarpathian Ugric Institute imeni Ferenc Rakotsi II; University of Economics and Law CROC. 
The accent is accentuated, that in Ukraine there will be more than one student living at material values, there will be a tendency to become more valuable, because there will be a loss of steel. Student youth in Ukraine also have a high standard of living, benevolence, universalism, security, tradition, comfort.

In the XXI century students in the United States and in Ukraine prefer an active life position, wish to develop spiritually and deepen their knowledge.

Key words: living values, students, transformation, information society of the XXI century, educational processes, educational potential, interactive tools.

Постановка проблеми. XXI століття характеризується неабиякою динамічністю соціально-економічного розвитку країн та зміною ідеологічних засад функціонування суспільств. Водночас підвищується роль соціокультурних чинників та інформаційних потоків, що зростають у геометричній прогресії, на ідентифікацію сучасного студентства. Зважаючи на це, формування ціннісних орієнтацій та життєвих позицій молодого покоління як в Україні, так і в США перебуває в стані динамічних трансформацій під впливом суспільних змін, превалюючих освітніх процесів та виховного потенціалу.

Україна 3 початку XXI століття, відновлюючи свою державну незалежність та розбудовуючи систему державних інституцій, зазнала значних трансформацій як у соціально-політичний сфері, так і в системі життєвих цінностей молоді. Ці зміни особливо активізувалися впродовж останніх шести років та продовжуються й досі. На перший план вийшли цінності, які давно стали ключовими в американському суспільстві, як-от: свобода, незалежність, конкурентоздатність, національна та особистісна гідність, патріотизм, неповторність і креативність, родина та соціальна відповідальність [5].

Аналіз особливостей трансформації життєвих цінностей сучасної студентської молоді важливий не лише для того, щоб відповідним чином організовувати навчання та виховання в закладі освіти, а й для того, щоб прогнозувати результативність розвитку системи вищої освіти.

Аналіз наукових досліджень і публікацій. Система ціннісних орієнтацій особистості студента вибудовується протягом тривалого часу в процесі навчання, дозвілля, спілкування, під впливом 3МI, глобальної мережі Інтернет тощо. Зважаючи на це, трансформація життєвих цінностей та ціннісних орієнтацій сучасної студентської молоді стала об'єктом грунтовних соціологічних, психологічних та педагогічних досліджень.

Окремі питання життєвих цінностей українських студентів вивчалися вітчизняними вченими М. Бліхар, І. Бурцевою, М. Свтухом, О. Сухомлинською, П. Ігнатенко, Н. Лапіним, Л. Бєляєвою, Т. Бутківською, О. Подольською, А. Кавалеровим та ін.

Трансформацію ціннісних орієнтацій у суспільстві розглядали О. Горбань, Л. Добровольська, О. Злобина, К. Коник, Т. Купрій, Л. Овсянкіна, С. Резнік, В. Тихонович, І. Третякова, Н. Прохорова, Ю. Шайгородський та ін.

Окремі аспекти проблеми життєвих цінностей молоді у США стали предметом наукових доробок американських дослідників, серед яких - М. Бін (M. Beane), Б. Гросс (B. Gross), Т. Гроулінг (Т. Grouling), К. Kepp (C. Kerr), В. Лечуга (V. Lechuga), Б. Нью- ман (В. Newman), Р. Реннер (R. Renner), К. Роджерс (C. Rogers), М. Сейден (M. Seiden), Х. Сміт (H. Smith), Д. Тіллман (D. Tillman), Г. Трагер (G. Trager), Е. Холл (E. Hall), Дж. Шет (J. Sheth). Американські практики М. Рокич (M. Rokeach) та Ш. Шварц (S. Schwartz) розробили методики вивчення термінальних та інструментальних життєвих цінностей студентів.

Водночас проблеми впливу сучасного виховного потенціалу та реформування освітнього процесу, продиктовані реаліями світового суспільного розвитку XXI століття, неабияк впливають на трансформацію життєвих цінностей студентської молоді як у США, так і в Україні, що потребує спеціального дослідження.

Мета статті - проаналізувати та зіставити особливості трансформації життєвих цінностей українських та американських студентів у XXI столітті у спектрі суспільних змін, превалюючих освітніх процесів та виховного потенціалу.

Виклад основного матеріалу. Життєві цінності студента розглядаються в дослідженні як основні його життєві орієнтири, котрі детермінують майбутню професійну спрямованість, визначають зміст навчально-виховної діяльності в закладі вищої освіти та окреслюють стиль і масштаби соціальної активності.

Варто наголосити, що взаємозв'язок життєвих цінностей особистості молодої людини та здобуття нею вищої освіти має двоякий характер. 3 одного боку, в процесі виховання та навчання в закладі вищої освіти формується система життєвих цінностей студента, а 3 іншого - кожен викладач, спілкуючись зі студентом, має справу з певною особистісною системою життєвих цінностей, яка водночас безпосередньо впливає на ефективність здобуття вищої освіти [4].

У сучасному суспільстві для значної частини населення здобуття освіти є не лише важливою, а й неодмінною цінністю. Однак для деяких людей такі цінності не пов'язані між собою: прагнучи здобути вищу освіту, вони не завжди виявляють бажання наполегливо працювати над складними завданнями, максимально поглиблюючи при цьому свої знання.

Означена вище ситуація характерна не лише для нашої країни. Так, Е. Графтон, дослідивши ситуацію в американських університетах, зазначає: «Значна кількість студентів приходять до університету, не відчуваючи особливого інтересу до своїх навчальних курсів... У кінцевому підсумку для більшості з них навчання в університеті - це не здобуття знань та вмінь, а отримання диплома, що дає можливість згодом влаштуватися на роботу» [3, с. 277]. Спостерігаючи за навчанням українських студентів, також можемо стверджувати, що для деяких із них характерним $є$ поверховість знань, бажання докласти мінімум зусиль, аби отримати хорошу оцінку, «закрити» сесію чи завершити навчання. Таким чином, слова Е. Графтона про те, що для значної кількості студентів метою навчання є не знання й уміння, а диплом про вищу освіту, є популярними і для України.

Цікаво, що така тенденція спостерігається саме в епоху інформатизації суспільства, коли більшість студентів проводить значну частину свого часу в мережі Інтернет, що є майже невичерпним джерелом інформації. Водночас зауважимо, що на сьогодні основною проблемоюєнебракінформації, аіїнадлишок, негативний вплив чого відображається на рівні як суспільної, так і індивідуальної свідомості. Неструктурованість, суперечливість, фрагментарність перманентного 
інформаційного потоку, що обрушується на свідомість людей, сприяє формуванню настільки ж суперечливої і фрагментарної картини світу [4, с. 50].

Однією $з$ важливих проблем сьогодення, яку необхідно вирішити в системі вищої освіти, є спрямованість освітнього процесу на те, щоб студент не лише глибоко вивчав обсяг інформації, що пропонується йому в аудиторії, а й здійснював її самостійний пошук та осмислення, провадив різноманітні дослідження, що стосуються його професії, а також умів коригувати власні життєві орієнтації відповідно до особистісних запитів та суспільних вимог.

Крім того, важливою стратегією освітнього процесу в закладі вищої освіти вважаємо усвідомлене «повернення» студентів зі світу переважно віртуального в реальний, що дає змогу усвідомити значущість наукового знання 3 його принципами об'єктивності, раціональності, істинності, достовірності та ін. Це має бути свідомим вибором людини на користь не так емоційно позитивних переживань, поверховості, розваг, як інтелектуальної роботи, критичного аналізу, наукового пізнання. Означене досить важливе ще й тому, що позиція людини як особи, що «поглинає інформацію», до позиції особи, яка «пізнає світ», - це крок до осягнення засобами управління та самоуправління, так зване «щеплення» від сліпої маніпуляції.

Як справедливо зазначає вітчизняний дослідник М. П. Бліхар, студентській молоді притаманні шість груп життєвих изіннісних орієнтацій, спрямованих на різні елементи вищої освіти, праці та професії, зокрема: 1) статусні (кар'єра, визнання в суспільстві та серед оточуючих, престиж); 2) самовираження в праuі (творчість, саморозвиток, розвиток особистості, професійне зростання); 3) споживацькі (матеріальне благополуччя); 4) індивідуальне самовдосконалення (самовдосконалення, розвиток особистості, інтелігентність); 5) альтруїстичні (спілкування у процесі праці); 6) спрямовані на професійну діяльність.

Ключовими ціннісними феноменами в структурі суб'єктивних цінностей студентства можемо виокремити життєві орієнтації на спілкування (матеріальна забезпеченість, бажана професія, самовдосконалення) та на захоплення (кар'єра, престиж, статус, матеріальна забезпеченість і самостійність) [1, с. 119]. Причому життєва орієнтація включає такі рівні:

- емоційний - характеризується соціальними почуттями;

- когнітивний - виражає свідому спрямованість на форми життєдіяльності;

- поведінковий - проявляється в готовності зайнятися тією чи іншою діяльністю [там само, с. 121].

Відзначимо, що США належать до індивідуалістських культур, де перевага надається передусім змаганням і конкуренції, а не кооперації та співпраці. Тому американські студенти завжди цінували право на особисту думку і погляди, приватну власність, свободу висловлювань та діяльності [5; 7].

Маріан Бін (Marian Beane), співзасновник Міжнародного наукового офісу Університету Північної Кароліни, наголошує, що навчально-виховний процес в американських закладах вищої освіти із початку XXI ст. орієнтується на такі життєві цінності студентів: індивідуальність (individuality) - студентам рекомендується бути незалежними і розвивати власні життєві цілі; конфідениійність (privacy) - студентам строюються умови, спрямовані на наявність приватного середовища, де вони зможуть проводити час на самоті; piвність (equality) - студентам надаються рівні освітні можливості незалежно від статі, раси, національності чи країни походження; повноцінне використання особистого часу та пунктуальність (time) - у студентів виховується життєва позиція «час - гроші», культивується прагнення уникати запізнень; неформальнicmь (informality) - проявляється як у комунікаційних взаєминах, так і в зовнішньому вигляді студентів та викладачів; досягнення та робота (achievement \& hard work/play) - конкурентоспроможний дух часто $\epsilon$ мотивуючим фактором для роботи і життя; прямота $i$ цілеспрямованість (direct \& assertive) - студентів орієнтують самостійно знаходити вихід із проблемної ситуації, спонукають постійно висловлювати власну думку, захищати свою позицію щодо вирішення проблемного питання; здатність дивитися в майбутне $i$ змінюватися (looking to the future and to change) студентів навчають орієнтуватися у своїй життєдіяльності не лише на ближні, а й далекі перспективи [6].

Відповідно до методик практиків М. Рокича (M. Rokeach) [8] та Ш. Шварца (S. Schwartz) [9] ocновними термінальними життєвими цінностями американських студентів на початку XXI ст. були: наявність сім’ї (родини); саморозвиток (індивідуальність); свобода вибору (висловлювань і діяльності); плюралізм і демократичність у суспільних відносинах; патріотизм та активна соціальна позиція; професіоналізм і конкурентоздатність; матеріальне становище; здоров'я. При цьому в сучасних американських закладах вищої освіти життєві цінності студентів формуються у процесі морального, ментального, релігійного, національного, полікультурного, патріотичного, громадського, естетичного, сімейного, соціально-політичного, здоров'язберігаючого виховання та професійного становлення [7]. 3 цією метою освітній процес передбачає створення відповідних інтерактивних зон, коучинг-формату, притаманного діяльності фідбек-векторного спрямування, Skype-простору та SPARK!LAB-простору.

Зважаючи на застосування у вищій освіті США інтерактивних інструментів, відбувається системне формування, динамічний розвиток та постійна модернізація життєвих орієнтирів студента, закріплення їх у життєвих цінностях, оскільки інтерактивне навчання впливає не лише на свідомість молоді, а й на іiї почуття, потреби, волю (дії, практику) та переконання. При цьому створюються сприятливі умови для досягнення паритету між життєвими цінностями молодої людини та прийнятними орієнтирами функціонування соціуму, тобто суспільства загалом.

Для визначення системи життєвих ціннісних орієнтацій українських студентів нами було застосовано комплексне дослідження, зокрема: здійснено анкетування за методикою М. Рокича; проведено серію формалізованих та глибинних інтерв'ю; запропоновано низку проєктивних тестів із використанням «методу незакінчених пропозицій», коли респондентам пропонується продовжити фразу «Під життєвими цінностями я розумію...»; запропоновано розроблену авторську анкету «Життєві цінності студента в умовах трансформації суспільних відносин та реформування системи вищої освіти».

Усього нами було опитано близько тисячі студентів різних спеціальностей та вікових категорій iз Харківської гуманітарно-педагогічної академії, Вінницького кооперативного інституту, Закарпатського угорського інституту ім. Ференца Ракоці II, Університету економіки та права «КРОК» (м. Київ). 
Результати комплексного дослідження засвідчили, що головною метою в житті сучасної української молоді є: створення сім’ї (58,7 \%), наявність престижної роботи і кар'єрного росту (54,9 \%), матеріальний достаток (44,3 \%), наявність вищої освіти $(37,1 \%)$, духовний розвиток $(35,4 \%)$. Тобто в ієрархії життєвих цінностей молодих людей пріоритетними є сімейні цінності. Так, мотивами створення сім'ї для більшості студентів насамперед є: любов $(97,1 \%)$, духовна близькість (45,7 \%), спільність поглядів (57,1 \%). Не забуває молодь і про друзів, які завжди підтримають і не залишать у біді (68,6 \%).

Зважаючи на це, сучасна українська студентська молодь вибудовує таку ієрархію життєвих цінностей, в якій на першому місці - любов (40 \%), на другому - працелюбність $(35,7$ \%), а на третьому - відповідальність (32,8 \%). Водночас молоді люди прагнуть екстриму та нових відчуттів, змінюють власні образи та експериментують, але при цьому залишаються стриманими та прагнуть матеріального добробуту, будують сміливі плани на майбутнє, формують життєві цілі, цінності та орієнтації, які стануть для них «дороговказом» на все життя.

Для життєвого світу сучасних українських студентів притаманні такі риси, як: спрямованість у майбутнє; перманентна стурбованість соціальними проблемами; пошук власного «Я»; багатовекторна спрямованість; динамічність; багатоманітність впливів та сфер самореалізації, наприклад, завдяки міжкультурній комунікації; відкритість у пошуку індивідуальних життєвих цінностей та ідеалів. Це, зокрема, підтверджують результати досліджень О. Горбаня, Т. Купрій та Л. Овсянкіної, що проводилися на базі Національного педагогічного університету ім. М. П. Драгоманова та Київського університету ім. Бориса Грінченка [2].

Таким чином, виховний вплив у закладах вищої освіти України сьогодні здійснюється на основі організації спеціальних освітніх курсів, семінарів, практикумів, дискусій та тренінгів; уроків особистої гідності, взаємоповаги та безконфліктної взаємодії в соціумі; створення рольових ситуацій; використання відеороликів, онлайн-комунікації тощо. Однак переконані, що корисним буде впровадження в освітній процес українських ЗВО американського досвіду щодо застосування інтерактивних інструментів, серед яких - інтерактивні зони, інтерактивні методи, формат коучингу, фідбек-векторне спрямування, Skype-простір та SPARK! LAB-простір, обернене (реверсне) заняття, кейс-метод, тайм-лайн, флешмоб, проєктне навчання, презентації, вебінари, лабораторія винаходів, майстер-класи тощо.

Сьогодні, на початку XXI століття, українська молодь є досить розкутою, позбавленою будь-якого страху, прагматичною, відкритою до майбутніх змін і здатною до нестандартних учинків, спроможною самостійно формувати конкретні життєві цілі, визначати власні смислові пріоритети, докладати максимум зусиль для досягнення поставленої мети.

Висновки. Отже, студентська молодь як у США, так і в Україні віддає перевагу активній життєвій позиції. Більшість молодих людей покладаються зазвичай на власні знання, здібності та сили, оскільки схильні вважати, що долю людини визначають вони самі, а не зовнішні чинники. У порівнянні із минулими поколіннями сучасне студентство сприймає життя більш одноосібно та прагматично.
Так, якщо раніше студенти більше дослухалися до досвіду попередніх поколінь, то сьогодні їм доводиться творити власний соціальний досвід взаємовідносин, покладаючись у більшості випадків лише на себе, що зумовлює суперечливі тенденції в їхній свідомості та поведінці.

В умовах постійних динамічних змін більшість американських студентів у своєму серці формують позитивні цінності, які як наслідок - стають основою досягнення життєвих цілей. Відповідно українській студентській молоді притаманна орієнтація на матеріальні цінності, однак тенденція щодо сім’ї як цінності залишається сталою. Крім того, в українських студентів у житті домінують такі цінності, як доброзичливість, універсалізм, безпека, традиційність, комфортність, а ще - потреба розвиватися духовно та поглиблювати свої знання.

Перспективи подальших наукових досліджень вбачаємо в експериментальному вивченні факторів, які чинять позитивний та негативний вплив на формування життєвих цінностей українських та американських студентів у XXI столітті.

\section{СПИСОК ВИКОРИСТАНОЇ ЛІТЕРАТУРИ}

1. Бліхар М. П. Ціннісні орієнтації студентської молоді України: соціологічний аналіз проблеми / М. П. Бліхар // Вісник Львівського університету. Львів, 2011. - Вип. 5. - С. 116-125. - (Серія «Соціологічна»).

2. Горбань О. Трансформація консолідуючих ціннісних орієнтацій сучасного українського студентства / О. Горбань, Т. Купрій, Л. Овсянкіна // Освітологічний дискурс. - 2019. - № 1/2 (24/25). URL: http://elibrary.kubg.edu.ua/id/eprint/26825/1/ Horban_\%20\%D0\%9E_Kuprii_T_Ovsiankina \%20L Osvitologichnyy\%20dyskurs $1-\overline{2} \% 2824-25 \% 29 . \mathrm{pdf}$ (дата звернення: 25.08.2019).

3. Графтон Э. Университеты Америки: почему они терпят поражение? / Э. Графтон // Вопросы образования. - 2012. - № 2. - С. 273-284.

4. Резнік С. М. Трансформація цінностей освіти в інформаційному просторі / С. М. Резнік // Теорія і практика управління соціальними системами. - 2015. - № 4. - C. 47-53.

5. Товканець Г. Особливості ціннісних орієнтацій студентської молоді в США / Г. Товканець // Вісник Львівського університету. - Львів, 2016. - Вип. 30. С. 253-261. - (Серія «Педагогічна»).

6. Beane M. An Adventure in American Culture \& Values / M. Beane // Mode of access. URL: http://www. internationalstudentguidetotheusa.com/ articles/culture. htm (дата звернення: 20.08.2019).

7. Renner R. The rise of the For-Profit University. Book Review / R. Renner, Ed. Higher, Inc. // The Journal of Higher Education. - 2003. - № 74 (1). - P. 108-111.

8. Rokeach M. The Nature of Human Values / M. Rokeach. - New York : Free Press, 1973. - 438 p.

9. Schwartz S. H. and Boehnke K. Evaluating the structure of human values with confirmatory factor analysis / S. H. Schwartz and K. Boehnke // The Journal of Research in Personality. - 2004. - P. 230-255.

Дата надходження до редакиії: 12.09.2019 p. 